\title{
JURNALBASICEDU
}

Volume 6 Nomor 1 Tahun 2022 Halaman 726 - 737

Research \& Learningin Elementary Education

https://jbasic.org/index.php/basicedu

\section{Penilaian dan Jenis Tes yang Dibuat Oleh Guru di Tingkat Sekolah Dasar}

\author{
Fitri Handayani $^{1 凶}$, Riqqah Annisa Maharani ${ }^{2}$, Yanti Fitria ${ }^{3}$ \\ Universitas Negeri Padang, Indonesia ${ }^{1,2,3}$ \\ E-mail: $\underline{\text { hfitri236@gmail.com }}{ }^{1}, \underline{\text { riqqahannisa1@gmail.com }}{ }^{2}$, yanti_fitria@fip.unp.ac.id ${ }^{3}$
}

\begin{abstract}
Abstrak
Guru harus bisa memilih prosedur penilaian yang sesuai sehingga dapat mengambil suatu keputusan dalam proses belajar mengajar, mampu meningkatkan serta mengembangkan prosedur penilaian yang sesuai dalam pengambilan suatu keputusan, melakukan penjumlahan maupun menafsirkan pencapaian dalam penilaian yang telah dirancang serta mampu menerapkan pencapaian penilaian dalam pembuatan suatu keputusan pada aspek pendidikan serta mengembangkan prosedur penilaian yang valid dengan mengacu pada informasi. Tidak hanya itu saja guru/pendidik harus tau apa saja jenis tes yang akan dibuat. Dimana jenis tes yang dimaksud. Penelitianmya menggunakan metode studi literatur (library research), yang didasari dengan kajian pustaka yang bertujuan untuk memperkuat dalam melakukan penganalisisan terhadap sumber dalam proses pembelajaran. Penelitiannya berawal dari perumusan suatu permasalahan yang dilanjutkan dengan penganalisisan mencapai penelitian. Pengumpulan data dalam studi literatur ini dilakukan dengan memerlukan hasil non tes yaitu dapat menelusuri jurnal melalui google cendekiawan dan beberapa referensi seperti buku, skripsi dan lain sebagainya. Penelitian dimulai dengan cara merumuskan tinjauan serta batasan variabel yang ditetapkan. Jurnal ini dapat kita telusuri dengan menggunakan kata kunci yaitu Kata kunci Peniliaian, Jenis tes yang dibuat oleh guru. Berdasarkan hasil penelitian menggambarkan bahwasanya model tersebut sesuai dalam pelaksanaan pembelajaran dikarenakanterdamparnya pencapaian penilaian perencanaan yang mencakup pendidik, siswa maupun pencapaian belajar dengan mengalami peningkatan yang berbeda-beda pada setiap penelitian.
\end{abstract}

Kata Kunci: Penilaian, Jenis Tes, Guru Sekolah Dasar

\begin{abstract}
Teachers must be able to choose appropriate assessments so that they can make decisions in teaching, be able to improve and develop appropriate assessment procedures in decision making, take action and control in designed decisions and be able to apply supervision to a decision on educational aspects and develop valid assessment procedures with reference to information. Not only that, teachers / educators must know what types of tests will be made. Where is the type of test in question. The research uses the literature research method, which is based on a literature review which aims to strengthen the analysis of the learning process. The research begins with the formulation of a problem followed by analysis to achieve research. Data collection in this literature study was carried out by requiring non-test results, namely being able to browse journals through Google Scholar and several references such as books, theses and so on. The research begins by formulating and determining the limits of the variables. We can search this journal by using keywords, namely Assessment Keywords, Types of tests made by the teacher. The results based on the research illustrate that the model is appropriate in the implementation of learning due to the stranding of the assessments achieved by educators, both students and learning with different improvements in each study.
\end{abstract}

Keywords: Assessment, Type of Test, Primary school teachers

Copyright (c) 2022 Fitri Handayani, Riqqah Annisa Maharani, Yanti Fitria

$\triangle$ Corresponding author :

Email : hfitri236@gmail.com

DOI : https://doi.org/10.31004/basicedu.v6i1.2033

ISSN 2580-3735 (Media Cetak)

ISSN 2580-1147 (Media Online)

Jurnal Basicedu Vol 6 No 1 Tahun 2022

p-ISSN 2580-3735 e-ISSN 2580-1147 


\section{PENDAHULUAN}

Berbagai tantangan terus berkembang dalam kehidupan masuia, termasuk dalam peningkatan kemampuan dan kemampuan manusia dalam kategori pendidikan. Untuk itu, pendidikan merupakan bagian dari tujuan umumnya memainkan peran mempersiapkan siswa yang mampu berpikir kritis, kreatif dan logis (Fitria, 2014). Dalam suatu proses pendidikan yang dijadikan pedoman pelaksanaan pendidikannya yakni kurikulum. Kurikulum ialah suatu yang memberikan dampak dalam proses pelaksanaan pembelajaran. Kesempurnaan kurikulum ialah upaya dalam meningkatkan mutu pembelajaran. Menurut Masyhud, (2014) Indonesia telah mengalami perubahan pada kurikulum, yakni 1947, 1964, 1968, 1973, 1975, 1984, 1994, 1997, 2004, 2006, dan terakhir 2013. Kurikulum yang sebelumnya terus mengalami perubahan dan perkembangan hingga saat sekarang ini yang memakai kurikulum 2013 dengan tujuan dan upaya untuk mengalami peruabahan dan peningkatan dalam hal ketercapaian proses pendidikan (Desi \& Fitria, 2019).

Pendidikan berhubungan dengan proses pelajaran ialah suatu kegiatan yang dapat terjadinya interaksi antar sesama dalam kegiatan pembelajaran serta sumber belajarnnya (AM et al., 2018). Pemahaman tentang kurikulum bagi guru dan tenaga kependidikan lainnya mutlak diperlukan, sebab kurikulum berfungsi sebagai pedoman penyelenggaraan proses pembelajaran (Siagian, 2021). Realitas ditemukan di lapangan hari ini adalah pembelajaran tematik tidak dieksekusi dengan baik (Fitria, 2018). Oleh karena itu, filosofi kurikulum yang yang diajarkan oleh guru akan memberikan pengaruh yang besar bagi proses pembelajaran anak didiknya.

Kegiatan pembelajaran dikatakan berhasil jika terdapat suatu perubahan dalam proses pembelajaran yang awalnya pendidik mempunyai peran yang besar dalam pelaksanaan proses pembelajaran menjadi proses belajar mengajar yang menitikberatkan pada siswa, yang menggunakan sistem pengevaluasian yang awalnya bersifat diskriminasi pada peserta didik menjadi diferensiasi pada peserta didik (Prananda, 2019). Perubahan pada proses pendidikan dijadikan sebagai penentu dalam pencapaian proses pendidikan. Kesesuaian dalam pengevaluasian yang dilaksanakan oleh sekolah terutama yang berhubungan dengan penilaian kelas serta menggambarkan suatu pencapaian belajar siswa. pengevaluasian ialah suatu tahapan yang dilakukan oleh pendidik untuk mengetahui potensi peserta didiknya (Setiadi, 2016). Penilaian juga dapat dikatakan suatu yang mempunyai peranan dalam proses pendidikan.

Kegiatan pelajaran ialah tahapan yang dapat menyembuhkan serta meningkatkan mutu dalam proses belajar mengajar yang terarah serta kompetitif (Ghufron, 2010). Kedudukan dalam suatu pengevaluasian mempunyai peranan dalam peningkatan keberhasilan dalam pelaksanaan proses pelajaran. information tidak hanya sebagai pertanggung jawaban saat kegiatan belajar mengajar tapi informasi yang disajikan sebagai pendukung dalam proses pelajaran (Kasih \& Purnomo, 2016). Dalam tahapan akhir pembelajaran maupun pendidikan serta pelatihan harus dilakukan suatu penyebarluasan yang bertujuan dalam mengetahui suatu keberhasilan dalam proses pendidikan maupun pengajaran serta pelatihan yang diadakan. Tidak hanya itu dalam pendidikan seorang guru juga dapat membuat atau mengetahui apa saja jenis tes.

Suatu kemampuan yang dimiliki oleh seorang pendidik tidak hanya dalam penyusunan instrumen pengevaluasian dalam mengetahui pencapaian pembelajaran pada siswa tetapi juga dijadikan sebagai pengevaluasian yang berfungsi sebagai instrumen dalam pengukuran pencapaian belajar mengajar (Fitrianawati, 2015). Seorang guru, harus mempunyai kemampuan serta menguasai berbagai aspek dalam proses belajar mengajar serta sistem informasi dalam pencapaian belajar siswa (Abdul Kadir, 2015). Ada banyak cara guru untuk mengkategorikan item tes. Klasifikasi skema pengkategorian item uji yang paling popular ada dua dimensi, yang pertama sesuai dengan metode penilaian dan yang kedua sesuai dengan kebebasan tanggapan siswa. 

Annisa Maharani, Yanti Fitria

DOI: https://doi.org/10.31004/basicedu.v6i1.2033

\section{METODE PENELITIAN}

Penelitian yang dilaksanakan berjenis studi literatur (library reseach) berdasarkan kajian pustaka yang bertujuan dalam memberikan penguatan terhadap penganalisisan dari berbagai referensi yang digunakan. Studi literature atau penelitian kepustakaan merupakan kegiatan mengumpulkan informasi dan data dari berberapa sumber referensi yang berkaitan dengan masalah yang dibahas. Menurut Arikunto studi kepustakaan merupakan jenis penelitian yang mengumpulkan data melalui pencarian informasi dari majalah, buku, koran, dan literatur lainnya dengan tujuan agar dapat menciptakan suatu landasan teori (Prasetyo et al., 2019).

Studi literatur bertujuan untuk mengumpulkan hasil penelitian yang berkaitan dengan tujuan penulisan yang akan dilakukan. Studi literatur juga merupakan suatu metode yang bertujuan untuk dapat mengumpulkan data dari beberapa bentuk sumber literature yang ada semacam jurnal-jurnal, dan referensi ilmiah lainnya yang akan dianalisis. Studi literatur juga dapat dikatakan sebagai kajian teoritis, rujukan hal ini berhubungan dengan tindakan baik dan buruk dan bagaimana menjalin rasa menghargai di masyarakat (Sugiyono, 2012). Sejalan dengan itu Surani, (2019) menjelaskan bahwa penelitian studi literatur juga dapat dipahami dengan serangkaian tindakan yang berkenaan dengan metode pengumpulan data pustaka, referensi secara relevan dengan kasus permasalahan untuk mengolah suatu materi .

Selanjutnya Sugiyono, (2012) berpendapat bahwa penelitian pustaka ialah penelitian terhadap pengkajian secara teoritis maupun di teratur ilmiah yang berhubungan dengan norma maupun nilai serta budaya yang terdapat dalam keadaan sosial yang diamati. Khatibah mengemukakan bahwa penelitian kepustakaan merupakan kegiatan menghimpun, pengelolaan serta penyimpulan data penelitian yang memakai metode tertentu untuk menemukan solusi akan masalah yang sedang terjadi (Danandjaja, 2014). Pada pengamatan ini penulis berusaha melihat bagaimana pendidik menilai dan menentukan jenis tes yang akan dibuatnya. Cara dalam mengumpulkan data yang dipakai saat pengamatan tersebut merupakan teknik studi literatur, ialah dilaksanakan melalui pengumpulan data dari beberapa sumber seperti buku, skripsi, artikel, jurnal yang telah dipublish maupun sumber relevan lainnya.

Dalam penelitian kepustakaan, peneliti harus mengikuti beberapa kaidah yang berlaku seperti mengidentifikasi berbagai teori dengan sistematis, penemuan pustaka, serta menganalisis dokumen berkenaan dengan informasi topik penelitian. Sehingga, ketika semua bahan kepustakaan telah terkumpul, maka seorang peneliti bisa menyusun bahan kepustakaan tersebut secara sistematis, kemudian mengelompokkanya untuk melihat relevan atau tidaknya data tersebut. Terakhir barulah peneliti menganalisis teori-teori tersebut.

Penelitian ini menggunakan metode analisis data deskriptif. Metode ini merupakan metode penganalisaan data diawali dengan mengemukakan fakta-fakta yang ada dan kemudian dianalisis. Kegiatan ini dilakukan bukan sekedar untuk menguraikan informasi, tetapi juga memberikan pemahaman dan penjelasan yang jelas.

\section{HASIL PENELITIAN DAN PEMBAHASAN}

\section{Penilaian}

Penilaian dalam kurikulum 2013 merupakan penilaian yang terdiri dari 3 aspek diantarnya ada aspek sikap, pengetahuan (kognitif) dan keterampilan (psikomotor). Kognitif mencakup hasil yang berhubungan dengan aspek pengetahuan, pemahaman, dan keterampilan berpikir. Menurut Permendiknas No. 20 Tahun 2007, agar proses evaluasi dapat berjalan dengan baik, maka evaluasi harus valid, objektif, adil, terbuka, menyeluruh dan berkesinambungan, sistematis, berdasarkan kriterianya.

Penilaian merupakan bagian penting dari kegiatan belajar mengajar di sekolah yang dilakukan setelah terjadinya proses transfer ilmu dari guru dan siswa di kelas. Penilaian dapat didefinisikan sebagai setiap kegiatan yang dilakukan guru dan siswa untuk memperoleh informasi yang dapat digunakan untuk mengubah 
proses belajar mengajar ke arah yang lebih baik. Ini termasuk pengamatan guru dan analisis pekerjaan siswa. Semua ini berkaitan dengan apa yang siswa ketahui atau tidak ketahui. Penilaian juga digunakan untuk memotivasi siswa meningkatkan pemahamannya dan untuk memenuhi harapan standar ketercapaiannya keberhasilan belajar. Oleh karena itu, tergantung pada bagaimana hasilnya digunakan, penilaian dikategorikan sebagai penilaian formatif dan sumatif.

Penilaian merupakan bagian dari proses pembelajaran karena berhasil tidaknya suatu proses pembelajaran hanya diketahui setelah adanya penilaian. Hayat, dkk dalam (Wildan, 2017) penilaian autentik adalah pengukuran atas hasil belajar peserta didik dalam menunjukkan tugas dan hasil kerjanya yang bermakna dari ranah sikap, keterampilan, dan pengetahuan. Penilaian autentik dapat juga dikatakan sebagai kegiatan menilai peserta didik yang menekankan pada apa yang seharusnya dinilai, baik proses maupun hasil dengan berbagai intrumen penilaian yang disesuaikan dengan tuntutan instrumen yang ada di Kompetensi Dasar (Kunandar, 2014).

Berdasarkan pernyataan di atas, dapat disimpulkan bahwa penilaian merupakan suatu proses yang dilakukan oleh guru terhadap peserta didiknya untuk mengukur seberapa tingkat keberhasilan peserta didik di dalam kelas. Hal ini berkaitan dengan penguasaan materi pelajaran, yang dilakukan secara berkelanjutan dan berkesinambungan. Dalam penilaian ini melatih semua hal dari dalam diri peserta didik, baik dari segi pengetahuannya, sikap dan juga keterampilannya. Penilaian dilakukan dengan memperhatikan beberapa instrumen yang mengukur tingkat karakteristik peserta didik. Apakah mereka mampu menjawab butir soal yang diberikan, makanya sebalum penilaian dilakukan ditentukan dulu tujuan dan juga kisi-kisi soalnya. Untuk menilai hasil penilaian ini harus dilakukan secara objektif terhadap apa yang dikerjakan anak.

Ciri-ciri evaluasi autentik adalah: 1). Dapat digunakan untuk format formatif dan sumatif. Artinya penilaian autentik dapat dilakukan dalam rangka mengukur kompetensi terhadap satu atau lebih kompetensi dasar (formatif) dan keberhasilan kompetensi terhadap standar kompetensi atau kompetensi inti dalam satu semester (sumatif), (2) mengukur keterampilan dan kinerja, tidak hanya dalam kategori hafalan dan fakta saja. Artinya, penilaian autentik harus mengukur pencapaian kompetensi yang menonjolkan aspek kemampuan (skills) dan kinerja (achievement), tidak hanya mengukur kompetensi faktual (hafalan dan memori), (3) Kontinu dan terintegrasi. Artinya, dalam melakukan penilaian autentik harus berkesinambungan (continuous) dan membentuk satu kesatuan yang utuh guna mengumpulkan informasi keberhasilan kompetensi siswa. (4) Dapat digunakan sebagai umpan balik. Artinya, evaluasi otentik dari guru dapat digunakan secara luas sebagai umpan balik atas prestasi siswa (Kunandar, 2014).

Pembelajaran yang tidak menerapkan metode serta media yang inovatif dapat membuat peserta didik tidak termotivasi dalam pelaksanaan kegiatan belajar, peserta didik tidak berkonsentrasi dalam belajar karena tidak terlibat langsung dalam pembelajaran dan dari beberapa persoalan yang ditemukan terdapat pengaruh pada pencapaian yang diperoleh. Kegiatan pembelajaran diupayakan lebih menekankan kepada pemahaman konsep supaya peserta didik memperoleh konsep dasar yang baik dalam mendapatkan kemampuan dasar lainnya seperti menganalisis, mengkomunikasikan, serta hubungan dalam pemecahan masalah (Suyono et al., 2017). Agar pembelajaran berjalan dengan semestinya pendidik mampu menerapkan model pelajaran inovatif. Menurut Rusman (dalam Hidayah, 2015) suatu pelaksanaan pembelajaran yang menuntut peserta didik untuk bekerjasama di dalam kelompok dalam menyelesaikan permasalahan disebut dengan model kooperatif. Dalam kegiatan belajar peserta didik ditekankan agar dapat melakukan sesuatu secara bersama sebagai satu kelompok atau satu tim (Hazmiwati, 2018). Sejalan dengan pendapat Hafid \& Asikin, (2020) pembelajaran kooperatif merupakan pembelajaran yang dilakukan dalam berkelompok dan setiap anak didik yang diarahkan pada cara berkomunikasi yang baik dengan teman dan gurunya dalam mencapai tujuan yang diharapkan. 

Annisa Maharani, Yanti Fitria

DOI: https://doi.org/10.31004/basicedu.v6i1.2033

\section{JENIS-JENIS PENILAIAN}

\section{Penilaian Formatif}

Suatu bentuk penilaian yang bertujuan dalam pencapaian hasil belajar siswa saat siswa selesai melaksanakan proses belajar mengajar pada suatu bidang studi pelajaran. Penilaian formatif berfungsi dalam perbaikan suatu tahapan pelajaran ke arah yang baik dalam suatu program maupun bidang studi (Yamirudeng \& Osman, 2019). Berdasarkan pangevaluasian tergambar bahwasanya penggunaan metode yang dipakai dalam satuan kebahasaan dari program studi pembelajaran yang berkaitan telah sesuai dengan durasi pembelajaran yang ditentukan.

Penilaian formatif bertujuan dalam penentuan potensi serta pencapaian dalam pelaksanaan tugas siswa mengenai pembelajaran yang telah berlangsung dalam durasi waktu yang telah ditentukan (Blegur et al., 2017). Berdasarkan pencapaian penilaian yang didapatkan mampu menyelesaikan pertanyaan misalnya apakah bahan pembelajaran perlu diulang, apakah pencapaian KD serta pertanyaan lainnya. Dalam menggunakan penilaian formatif yang dijadikan sebagai objek penilaian yakni mengacu pada kompetensi dasar yang memuat tentang kognitif, afektif, serat psikomotorik maupun penugasan mengenai pembelajaran yang telah ditentukan oleh pendidik. Dalam penganalisisan suatu kompetensi dasar dapat dilakukan dengan berupa tes yang mampu melakukan pengujian terhadap pencapaian suatu kompetensi dasar.

Dalam proses pembelajaran menggunakan durasi yang bertujuan dalam melakukan evaluasi secara formatif ialah suatu aspek yang berkaitan dengan pemberian penilaian yang dilakukan setelah pembelajaran berakhir bisa pada saat 1 subtema bakan bisa dalam 1 tema. Proses penyebarluasan dengan menggunakan penilaian formatif dapat dilakukan saat proses pelajaran kelas selesai.

\section{Penilaian Sumatif}

Penilaian sumatif dapat digunakan dalam penentuan pencapaian murid saat mengikuti pembelajaran yang berfungsi dalam penentuan nilai pada murid setelah selesai melaksanakan pembelajaran pada satu caturwulan maupun semester akhir tahun serta akhir dari semester program bahan pengajaran dari satuan pendidikan.

Penilaian ini bertujuan dalam memberikan penjelasan mengenai suatu pengevaluasian dalam penentuan hasil belajar murid hingga mampu memahami potensi yang dimiliki murid pada satu caturwulan semester akhir tahun maupun akhir program sehingga bahan pengajaran dapat dilakukan setelah melaksanakan suatu penilaian secara sumatif (Barokah, 2019).

Dalam penilaian secara sumatif terdapat beberapa point yang meliputi aspek kognitif serta psikomotorik maupun penyelesaian suatu tugas yang telah disajikan oleh pendidik mengenai bahan pelajaran yang telah dijelaskan. Dalam proses pembelajaran dengan menggunakan penilaian secara objektif memerlukan durasi yang sesuai dengan penilaian caturwulan serta semester maupun akhir tahun saat selesai melaksanakan proses pembelajaran maupun bahan pembelajaran dalam satuan pendidikan.

\section{Penilaian Penempatan (Placement)}

Penilaian penempatan meliputi suatu hidangan penyuluhan terhadap sekolah yang berfungsi dalam memahami kondisi peserta didik serta kepribadian peserta didik saat mengikuti proses belajar mengajar supaya peserta didik mampu menyesuaikan dengan potensi maupun kepribadian yang dimilikinya (Pratiwi Pujiastuti, Sekar Purbarini Kawuryan, 2017). Misalnya didalam kelas guru bisa menempatkan peserta didik yang berbadan kecil duduk bagian baris terdepan. Bisa juga peserta didik yang memiliki masalah penglihatan bisa ditempatkan duduk di baris terdepan juga. Disini dapat dilihat bahwa penilaian yang dilakukan guru berfungsi sebagai penempatan sesuai dengan kemampuan dan karakteristik siswa. penempatan ini bisa juga dilakukan untuk bakat peserta didik. Misalnya anak yang memiliki bakat yang sama dalam kategori menggambar bisa ditempatkan dan daisatukan ditempat yang sama. 
Penilaian ini bertujuan dalam penentuan suatu potensi yang dimiliki oleh murid saat melaksanakan kegiatan pembelajaran bersama pendidikan sehingga mampu menempatkan peserta didik pada kedudukannya yang didasari pada bakat serta minat maupun kemampuan serta kesanggupan siswa dalam mengkondisikan serta tidak mengalami kendala saat mengikuti proses belajar mengajar. Misalnya yang telah diuraikanpencapaian belajar masih tergolong rendah dalam peningkatannya bahwasanya tinggi rendahnya pencapaian belajar dikarenakan terdapatnya pengaruh dalam proses belajar mengajar misalnya yang terjadi pada pendidik maupun fasilitas serta lingkungan maupun kepribadian peserta didik. Jika kemampuan peserta didik mengalami peningkatan maka dikarenakan faktor peserta didik yang berkaitan dengan bakat maupun minat serta kemampuan maupun kepribadian pada peserta didik. maka dari itu untuk menunjang penilaian ini dapat dilakukan dengan penggunaan test psikis yang standarsehingga mampu memainkan peran intelegensi maupun bakat serta minat terhadap suatu tes kepribadiannya

Dalam pelaksanaan ini durasi waktu yang diperlukan yakni sebelum peserta didik melaksanakan kegiatan belajar mengajar yang permulaan. saat peserta didik menyelesaikan proses belajarnya di bangku SMA seperti peserta didik selanjutnya melanjutkan pendidikannya di instansi tinggiseharusnya melakukan penilaian psikis yang berkaitan dengan bakat maupun minat serta kepribadian peserta didik sehingga mampu memilih dan memilah maupun tindak lanjut terhadap studinya.

\section{Penilaian Diagnostik}

Misalnya dalam melakukan penilaian penempatan maupun penilaian diagnostik dalam penentuan studi bimbingan maupun penyuluhan (Artikel, 2015). Fungsi permasalahan yang terjadi pada peserta didik dapat diakibatkan oleh faktor-faktor seperti peserta didik yang sering bolos saat pembelajaran matematika disebabkan pembelajaran dilaksanakan oleh guru kurang menyenangkan sehingga peserta didik membenci mata pembelajaran matematika dan dikarenakan peserta didik kesulitan dalam mengikuti serta memecahkan suatu permasalahan yang berkaitan dengan matematika yang telah disajikan oleh pendidik. Menurut Budyartati, (2016) dalam kegiatan ini penilaian diagnostik sangat diperlukan dikarenakan penilaian diagnostik mampu mengetahui serta memecahkan suatu permasalahan yang terdapat pada peserta didik yang menyebabkan peserta didik mengalami gangguan dalam mengikuti proses belajar mengajar yang berlangsung. dengan mengetahui faktor yang dapat mempengaruhi suatu permasalahan yang terdapat pada peserta didik sehingga pendidik mampu mengatasi serta mencegah terjadinya permasalahan pada diri peserta didik dengan menggunakan berbagai cara.

Dari uraian diatas maka penilaian ini bertujuan dalam membantu serta mengatasi masalah yang terjadi pada siswa yang mencangkup suatu permasalahan yang meliputi dampak-dampak yang mempengaruhinya.

Saat pelaksanaan penilaian yang menggunakan durasi waktu yang telah ditentukan sesuai dengan kebutuhannya penilaian ini dapat digunakan sebagai pendukung dalam memahami potensi maupun kepribadian pada peserta didik. Ada beberapa ketentuan dalam penilaian yang dibuat oleh guru, diantaranya:

\section{Jenis item apa yang harus digunakan?}

Ada banyak cara untuk mengkategorikan item tes. Klasifikasi skema pengkategorian item uji yang paling popular ada dua dimensi, yang pertama sesuai dengan metode penilaian dan yang kedua sesuai dengan kebebasan tanggapan siswa. Tes yang dinilai secara objektif disebut item uji objektif dan item yang meminta teknik penilaian lebih subjektif disebut item subyektif. Misalnya, benar-salah diklasifikasikan sebagai item yang obyektif karena jawabannya adalah skor yang benar atau salah sesuai dengan item yang telah ada. Tes esai adalah contoh yang paling umum dari item yang dinilai secara subjektif (Tenbrink, 1974). Dalam penilaian sebuah tes esai, guru harus membuat keputusan subyektif tentang seberapa dekat jawaban siswa dengan kunci jawaban. 
Cara kedua untuk mengkategorikan item tes adalah sesuai dengan kebebasan yaitu izinkan siswa itu membuat jawabannya. Tipe objektif, biasanya ada dua jenis : (1) item seleksi dan (2) item persediaan. Contoh tipe pertama adalah benar-salah, pilihan ganda, dan pertanyaan yang cocok. Item jenis penawaran adalah pertanyaan kosong dan jawaban singkat. Subali, (2013) membedakan antara item esai respon yang dibatasi dan tanggapan yang diperluas item esai.

Jenis item uji yang akan digunakan ditentukan oleh empat faktor :

a. Tingkat (dan jenis) hasil belajar diukur

b. Cara di mana hasil tes akan digunakan

c. Karakteristik siswa yang mengikuti tes

d. Waktu yang tersedia untuk membangun, mengelola dan menilai tes

Karena masing-masing jenis item uji diperkenalkan, keempat faktor ini akan menjadi pertimbangan.

\section{Menjodohkan (Matching)}

Mempertemukan item terbaik/cocok untuk perolehan informasi tentang pengetahuan fakta seseorang. Dalam soal yang disediakan berjenis satu seri pertanyaan serta satu seri jawaban yang mana pertanyaan mempunyai jawaban dalam beberapa pilihan jawaban yang telah disediakan. peserta didik bertugas dalam penyelesaian serta pencarian jawaban atas soal yang telah disediakan sehingga mampu menjodohkan dengan jawaban yang benar sesuai dengan soal yang telah disediakan (Ridho, 2018). Pengevaluasian ini berguna dalam mengetahui serta mengukur potensi dalam pengidentifikasian terhadap beberapa hal. pengevaluasian ini terdiri atas dua lajur yang mana terdapat lajur kiri yang berisi suatu pertanyaan yang belum lengkap sedangkan lajur kanan terdapat soal dengan jawaban yang lengkap.

\section{Contoh Pencocokan Item}

Pilih istilah di sebelah kiri yang cocok dengan yang ada di sebelah kanan. Anda bisa menggunakan istilah di sebelah kanan lebih dari satu kali.
1. Benar-salah
a. Tujuan, penawaran
2. Pencocokan
b. Tujuan, seleksi
3. Batasan terbatas
c. Respons subyektif dan terbatas
4. Jawaban yang diperluas
d. Respons subyektif dan diperpanjang
5. Jawaban singkat
6. Pilihan ganda

\section{Tanggapan alternatif (Alternative Response).}

Jenis yang paling umum materi tanggapan alternatif adalah benar-salah item. Suatu bentuk tes di mana itemnya berupa pernyataan yang mengandung dua kemungkinan: benar atau salah (Maysarah \& Setiana, 2021). Tetapi statemen itu sebenarnya hanya memilki satu kemungkinan, yaitu bias benar atau hanya bias salah, peserta di minta untuk menentukan pilihannya terhadap statemen tersebut dengan memilih salah satu diantara benar dan salah.

\section{Contoh Item Respon Alternatif}

1. Item benar-salah adalah item alternatif-respons.

a. Benar

b. Salah

2. Manusia roti jahe akhirnya tertangkap.

a. Iya

b. Tidak

3. Untuk masing-masing gambar desain interior berikut, putuskan apakah ada atau tidak contoh dari fitur desain kontemporer. 

Annisa Maharani, Yanti Fitria

DOI: https://doi.org/10.31004/basicedu.v6i1.2033

\section{Item pilihan ganda (Multiple Choice).}

Pilihan banyak Item, mungkin item yang paling serbaguna dari tipe sasaran. Tes pilihan ganda merupakan tes obyektif, yang menyajikan dua atau lebih jawaban, dan hanya satu dari pilihan-pilihan tersebut yang benar atau lebih baik dari yang lainnya.

\section{Contoh Pilihan Ganda Item}

\section{TINGKAT PENGETAHUAN}

1. Manakah dari jenis item berikut yang biasanya dianggap subjektif item?
a. Benar atau salah
b. Essay
c. Pilihan ganda
d. Sesuai

\section{TINGKAT ANALISIS}

2. Bagian bicara apa yang digarisbawahi dalam kalimat berikut?

John dengan bersemangat memainkan bola.
a. Kata benda
b. Kata kerja
c. Kata sifat
d. Kata keterangan

\section{Isi yang kosong (fill the blank).}

Sebuah pernyataan dibuat dan sebuah kata atau frase ditinggalkan dan dicampur dengan tanda kosong atau tanda tanya. Siswa tersebut kemudian diminta untuk mengisi kolom kosong dengan kata atau frase yang tepat. Sulit untuk mendapatkan pemahaman, aplikasi, analisis, dan tingkat per level, hasil belajar yang kompleks dengan jenis item ini, tapi jika perhatian tidak dilakukan, itu bisa menjadi sulit untuk penilaian.

Contoh Item Isi yang Kosong

1. Perang Korea dimulai secara resmi di tahun ...

2. Presiden Amerika Serikat yang pertama adalah

George ...

\section{Jawab singkat (Short Answers).}

Diperlakukan sebagai transisi antara item isi yang kosong dan esai, sebuah pertanyaan sederhana diajukan dan siswa diminta memberikan jawaban singkat (biasanya ungkapan satu atau dua kalimat).

\section{Contoh Item Jawaban Singkat \\ 1. Seperti apa cuaca saat Jodi dan Sue memulai penerbangan mereka dengan pesawat terbang? \\ 2. Sebutkan dua cara di mana item tes dapat diklasifikasikan}

\section{Esai respon terbatas (Restricted Response Essay)}

Esai respons terbatas memungkinkan siswa untuk menunjukkan seberapa banyak informasi yang dapat dia ingat dari memori. Keterbatasan mencakup format isi, dan ruang lingkup jawaban. Jadi soal tes uraian ini harus menentukan batas jawaban yang dikehendaki. 

Annisa Maharani, Yanti Fitria

DOI: https://doi.org/10.31004/basicedu.v6i1.2033

\section{Esai yang diperluas (Extended Response Essay)}

Item esai respon yang diperluas sangat berbeda untuk mendapatkan skor secara obyektif, tapi mereka membiarkan siswa memiliki banyak tanggapan di dalam jawabannya. Konsekuensinya, keterampilan kreatif, kemampuan mengatur dan menyajikan ide yang orisinil, atau kemampuan untuk mempertahankan suatu posisi atau mengevaluasi beberapa produk dapat diukur dengan item semacam ini. Jawaban yang diberikan oleh peserta tes hampir tidak ada batasan. Peserta tes memiliki kebebasan yang luas sekali untuk mengorganisaikan dan mengekspresikan gagasan pikirannya dan gagasan dalam menjawab soal tersebut. Jadi jawaban siswa bersifat terbuka, fleksibel, tetapi tetap focus dan terorganisir.

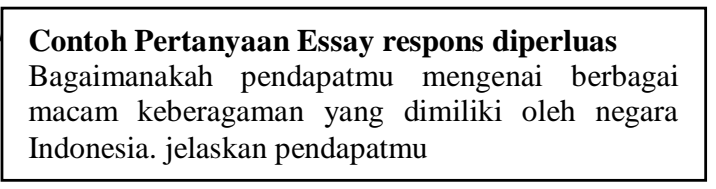

\section{Berapa Banyak Item yang Harus Digunakan?}

Jumlah item yang akan digunakan sering ditentukan oleh jumlah waktu tersedia. Namun, jika dibutuhkan lebih dari lima puluh menit, tes biasanya bisa dilakukan dibagi dua dan masing-masing setengahnya bisa diberikan pada hari yang berbeda.

Terkadang aturan praktisnya "Satu item pilihan ganda per menit" digunakan. Tapi peraturan ini juga mengikuti modifikasi oleh situasi tertentu. Jika siswa adalah pembaca yang lambat, maka satu item per menit tidaklah cukup untuknya. Jika itemnya panjang dan butuh banyak pemikiran, maka ini juga butuh banyak waktu untuknya. Di sisi lain, jika tes tersebut mencakup banyak item tipe memori pendek, maka satu item pilihan ganda per menit adalah membuang dari waktu yang akan digunakan.

Faktor yang paling penting terkait dengan lamanya tes adalah reliabilitas dari tes. Semakin lama tes, semakin tinggi reliabilitasnya. Pada tahap pertama dari proses evaluasi, kita akan membuat beberapa penilaian tentang pentingnya keputusan yang kita buat dan tentang keakuratan informasi dibutuhkan.

\section{Seberapa sulit itemnya?}

Pertimbangan utama dalam menentukan tingkat kesulitan tes adalah jenis penilaian dan keputusan yang kita gunakan. Jika membuat keputusan pemilihan yang memerlukan referensi norma penilaian, item harus berada pada tingkat kesulitan sekitar 50 persen. Ini berarti bahwa sekitar setengah dari siswa harus mendapatkan item yang benar. Jelas, setiap item dalam tes tidak akan sama persis dengan tingkat kesulitan 50 persen, tapi skor rata-rata untuk tes secara keseluruhan harus sekitar 50 persen. Saat ujian kira-kira tingkat kesulitan 50 persen, skornya menyebar lebih jauh dan memungkinkan kita membuat penilaian tentang kinerja siswa mana yang lebih baik dari yang satunya lagi

Saat penilaian kriteria-referensi dibuat, tingkat kesulitannya akan bervariasi sesuai dengan tingkat kinerja siswa dan jumlah variasi yang ada diantara para siswa. Tes ini mungkin akan tampak mudah saat penilaian penguasaan dilakukan karena mayoritas siswa diharapkan tampil di level tinggi kecakapan. Saat penilaian diskriminasi dilakukan, tingkat 50 persen kesulitan lagi akan diantisipasi.

Jika siswa tidak tahu bahannya dengan baik, itemnya mungkin akan sulit, dan kalau muridnya tahu materi dengan baik, item kemungkinan akan mudah. Namun, kesulitannya dari item juga ditentukan oleh bagaimana item itu ditulis. Seseorang yang sangat yang akrab dengan materi pelajaran tertentu bisa menulis item yang sangat sulit sehingga kebanyakan siswa akan salah.

Kesulitan suatu item dapat dimanipulasi dengan cara seperti kosa kata yang digunakan, struktur kalimat yang digunakan, dan dalam kasus pilihan ganda (alternatif yang tidak benar). Mungkin pendekatan terbaik untuk menulis item adalah mencoba mengukur secara langsung. 

Annisa Maharani, Yanti Fitria

DOI: https://doi.org/10.31004/basicedu.v6i1.2033

\section{Bagaimana seharusnya item disajikan?}

Item uji obyektif biasanya disajikan dalam bentuk buklet (diketik dan duplikat). Item esai bisa diduplikasi atau, dalam beberapa kasus, tertulis di papan tulis. Namun, item tes bisa disajikan secara lisan maupun tertulis.

Presentasi lisan berguna bila siswa adalah pembaca miliki cacat fisik yang membuat mereka sulit membaca item dari cetak. Terkadang perekam atau rekaman bisa menjadi rangsangan untuk pertanyaan bila presentasi tercetak tidak akan mungkin dilakukan. Item uji biasanya dipresentasikan ke seluruh kelompok individu di waktu yang sama. Misalnya, dengan mempresentasikan tes kepada satu siswa di suatu saat, guru bisa mendapatkan beberapa gagasan tentang proses yang digunakan siswa tersebut untuk menjawab pertanyaan. Sebagian besar tes diberikan di kelas, dengan buku ditutup, dan dengan hati-hati waktunya.

\section{Bagaimana Siswa Merespon?}

Tes obyektif dapat dinilai lebih mudah jika siswa merespons secara terpisah lembar jawabannya. Namun, jika ini tidak praktis, maka pengaturan lainnya bisa dilakukan. Pertanyaan esai biasanya ditanggapi secara tertulis, tapi respons lisan bisa jadi berharga karena seorang siswa bisa menghasilkan respon yang jauh lebih lama dalam waktu yang lebih singkat. Tentu saja, respon lebih sulit dinilai dari pada yang tertulis.

\section{Kriteria untuk format tes yang baik}

a. Siswa harus mampu memahami pertanyaan.

b. Siswa harus mempunyai waktu untuk berpikir tentang jawaban

c. Siswa harus mempunyai waktu untuk membuat suatu tanggapan sesuai

d. Para siswa harus yang mampu bagaimana membuat tanggapan (menuliskan suatu jawaban) meskipun demikian tidak harus yang benar.

\section{KESIMPULAN}

Pengevaluasian ialah tahapan atau pelaksanaan yang dilakukan dalam proses pembelajaran yang mempunyai hubungan bertujuan dalam pengumpulan informasi mengenai tahapan serta pencapaian belajar siswa. Pentingnya saat pelaksanaan aktivitas pembelajaran ialah pengevaluasian. Fungsi pengevaluasian yaitu penelusuran, pengecekan, pencarian, penyimpulan. Jenis-jenis penilaian antara lain berupa penilaian formatif, penilaian sumatif, enilaian penempatan, penilaian diagnostic, penilaian tes. Teknik penialaian berupa teknik evaluasi (tes dan non tes). Langkah dalam konstruksi uji adalah menentukan format tes. Ini berarti bahwa Anda harus memutuskan (a) jenis item apa yang harus digunakan, (b) berapa banyak item harus digunakan, (c) seberapa sulit itemnya, (d) bagaimana item harus dipresented, dan (e) bagaimana siswa harus merespon. Jenis item tes yang Anda putuskan untuk digunakan ditentukan oleh empat faktor: (a) tingkat (dan jenis) hasil pembelajaran yang diukur, (b) cara hasil hasilnya digunakan, (c) karakteristik siswa yang mengikuti tes, dan (d) ketersediaan waktu Pemograman untuk membangun, mengelola, dan mencetak ujian.

\section{UCAPAN TERIMA KASIH}

Terima kasih kami ucapkan kepada pada ibu Dr. Yanti fitria, M.Pd dan teman-teman yang ikut membantu dalam menyelesaikan artikel ini sehingga bisa terwujud dan bisa menjadi pedoman bagi peneliti lainnya dalam melakukan riset 


\section{DAFTAR PUSTAKA}

Abdul Kadir. (2015). Menyusun Dan Menganalisis Tes Hasil Belajar Abdul Kadir. Al-Ta'dib, 8(2), 70-81.

Am, I. A., Saputra, S. Y., \& Amelia, D. J. (2018). Pembelajaran Tematik Integratif Pada Kurikulum 2013 Di Kelas Rendah Sd Muhammadiyah 07 Wajak. Jinop (Jurnal Inovasi Pembelajaran), 4(1), 35. Https://Doi.Org/10.22219/Jinop.V4i1.4936

Artikel, I. (2015). Analisis Hasil Penilaian Diagnostik Kemampuan Berpikir Kritis Matematis Siswa. Unnes Journal Of Mathematics Education Research, 4(2), 139-145.

Barokah, M. (2019). Manajemen Penilaian Sumatif Pada Ranah Kognitif Pembelajaran Pai Kelas X Semester Ganjil Di Sma Negri 2 Pontianak Tahun Pelajaran 2017/ 2018. Al-Idarah: Jurnal Kependidikan Islam, 9(2), 159-179.

Blegur, J., P. Wasak, M. R., \& Manu, L. (2017). Penilaian Formatif Peserta Didik Atas Kompetensi Pendidik Dalam Proses Pembelajaran. Satya Widya, $33(2), \quad 117-127$. Https://Doi.Org/10.24246/J.Sw.2017.V33.I2.P117-127

Budyartati, S. (2016). Tes Kognitif Diagnostik Untuk Mendeteksi Kesulitan Belajar Siswa Sekolah Dasar. Premiere Educandum: Jurnal Pendidikan Dasar Dan Pembelajaran, 1(01), 40-50. Https://Doi.Org/10.25273/Pe.V1i01.34

Danandjaja, J. (2014). Metode Penelitian Kepustakaan. Antropologi Indonesia, O(52). Https://Doi.Org/10.7454/Ai.V0i52.3318

Desi Indriyani, Yanti Fitria, I. (2019). Jurnal Basicedu. Jurnal Basicedu, 5(3), 1683-1688.

Fadhilaturrahmi, Fadhilaturrahmi, And Rizki Ananda. 2018. "Evaluasi Pembelajaran Ips Berbasis Taksonomi Bloom Dua Dimensi Di Sekolah Dasar.” Jurnal Basicedu 1(2): 12-21.

Fitria, Y. (2014). Refleksi Pemetaan Pemahaman Calon Guru Sd Tentang Integrated Sains Learning. Pedagogi, Xiv(2), 82-87.

Fitria, Y. (2018). Perubahan Belajar Sains Siswa Sekolah Dasar Pada Pembelajaran Terintegrasi (Terpadu) Melalui Model Discovery Learning. Jurnal Inovasi Pendidikan Dan Pembelajaran Sekolah Dasar, 2(2), 52. Https://Doi.Org/10.24036/Jippsd.V2i2.102705

Fitrianawati, M. (2015). Peran Analisis Butir Soal Guna Meningkatkan Kualitas Butir Soal, Kompetensi Guru Dan Hasil Belajar Peserta Didik. Prosiding Seminar Nasional Pendidikan Pgsd Ums \& Hdpgsdi Wilayah Jawa, 5(3), 282-295. Isbn 978-602-70471-2-9 Peran.

Ghufron, A. (2010). Integrasi Nilai-Nilai Karakter Bangsa Pada Kegiatan Pembelajaran. Jurnal Cakrawala Pendidikan, 1(3), 13-24. Https://Doi.Org/10.21831/Cp.V1i3.230

Hafid, R., \& Asikin, A. (2020). Syamsinar, Firawati Rahman Hafid Elihami, Akbar Asikin. Maspl Journal, 1, $81-90$.

Hazmiwati. (2018). 178 Model Pembelajaran Kooperatif Tipe Stad, Hasil Belajar Ipa Hazmiwati. Jurnal Primary Program Studi Pendidikan Guru Sekolah Dasar Fakultas Keguruan Dan Ilmu Pendidikan Universitas Riau | Volume 7 | Nomor 1 | April 2018 | Issn: 2303-1514 | E-Issn: 2598-5949, 7(April), $178-184$.

Hidayah, N. (2015). Pembelajaran Tematik Integratif Di Sekolah Dasar. Ejournal.Radenintan.Ac.Id, 2, 33-49.

Kasih, P. A., \& Purnomo, Y. W. (2016). Peningkatan Hasil Belajar Matematika Siswa Sekolah Dasar Melalui Pembelajaran Berbasis Penilaian. Jramathedu (Journal Of Research And Advances In Mathematics Education), 1(1), 69-78. Https://Doi.Org/10.23917/Jramathedu.V1i1.1776

Kunandar. (2014). Penilaian Autentik Suatu Pendekatan Praktis. Pt. Raja Grafindo Persada.

Masyhud. (2014). Perubahan Kurikulum Di Indonesia: Studi Kritis Tentang Upaya Menemukan Kurikulum Pendidikan Islam Yang Ideal. Raudhah, Iv(1), 49-70. 
Maysarah, D., \& Setiana, S. M. (2021). Tanggapan Responden Terhadap Media Pembelajaran Alternatif Katagana. Jurnal Bahasa, Sastra, Dan Budaya (Mahadaya), 1(1), 33-42.

Prananda Gingga, H. (2019). Korelasi Antara Motivasi Belajar Dengan Hasil Belajar Siswa Dalam Pembelajaran Ipa Di Sekolah Dasar. Jurnal Basicedu, 3(3), 909-915.

Prasetyo, R. I., Hidayat, N., \& Dimas, A. (2019). Studi Literature Model Pembelajaran Poe. Penguatan Pendidikan \& Kebudayaan Untuk Menyongsong Society 5.0, 704-710.

Pratiwi Pujiastuti, Sekar Purbarini Kawuryan, Dan U. A. (2017). Evaluasi Pembelajaran Tematik Di Sekolah Dasar Pratiwi. Jurnal Kependidkan, 4(2), 187-199.

Ridho, U. (2018). Evaluasi Dalam Pembelajaran Bahasa Arab. An Nabighoh Jurnal Pendidikan Dan Pembelajaran Bahasa Arab, 20(01), 19. Https://Doi.Org/10.32332/An-Nabighoh.V20i01.1124

Setiadi, H. (2016). Pelaksanaan Penilaian Pada Kurikulum 2013. Jurnal Penelitian Dan Evaluasi Pendidikan, 20(2), 166-178. Https://Doi.Org/10.21831/Pep.V20i2.7173

Siagian, G. (2021). Jurnal Basicedu. Jurnal Basicedu, 5(3), 1683-1688.

Subali, B. (2013). Bias Item Tes Keterampilan Proses Sains Pola Divergen Dan Modifikasinya Sebagai Tes Kreativitas. Jurnal Penelitian Dan Evaluasi Pendidikan, 14(2), 309-334. Https://Doi.Org/10.21831/Pep.V14i2.1084

Sugiyono. (2012). Metode Penelitian Kuantitatif Kualitatif Dan R\&B. In Bandung: Alfabeta.

Surani, D. (2019). Studi Literatur: Peran Teknolog Pendidikan Dalam Pendidikan 4.0. Prosiding Seminar Nasional Pendidikan Fkip, 2(1), 456-469.

Suyono, Titik, H., \& Wulandari, I. S. (2017). Implementasi Gerakan Literasi Sekolah Pada Pembelajaran Tematik Di Sekolah Dasar. Sekolah Dasar: Kajian Teori Dan Praktik Pendidikan, 26(2), 116-123.

Tenbrink, T. D. (1974). Evaluation: A Practical Guide For Teacher. In Amerika: Mcgraw-Hill.

Wildan, W. (2017). Pelaksanaan Penilaian Autentik Aspek Pengetahuan, Sikap Dan Keterampilan Di Sekolah Atau Madrasah. Jurnal Tatsqif. Https://Doi.Org/10.20414/Jtq.V15i2.3

Yamirudeng, K., \& Osman, Z. (2019). Penilaian Formatif Bahan Pengajaran Dan Pembelajaran Bahasa Melayu Sebagai Bahasa Asing Di Thailand. Pendeta Journal Of Malay Language, Education And Literature, 10, 91-105. Https://Doi.Org/10.37134/Pendeta.Vol10.7.2019 